DANDELION

postgraduate arts journal \& research network

VOLUME 4 NUMBER 2 WINTER 2013
JOHN O'Brien is a Murray Scholarship PhD candidate in History of Art at Birkbeck, University of London and holds a Master's degree in Art History. His research considers Baroque ceilings in Rome in relation to new philosophical and cosmological systems of the sixteenth and seventeenth centuries.

\title{
'Little Heaven': Biodiversity and Beauty in the Landscape Paintings of Andrew Gifford
}

\author{
John O’Brien
}

In the first week of July 2013 I travelled down to Brighton to the Phoenix Gallery, where landscape artist Andrew Gifford has his studio, to interview him about his latest exhibition, a set of works commissioned for Glyndebourne's Mildmay Gallery. The paintings are based on a landscape about a mile west of Glyndebourne, East Sussex, in an area of farmland known locally as 'Little Heaven', after which the exhibition is named.

Gifford found his subject by chance. While driving back from the site of the Glyndebourne opera festival he looked over his shoulder and saw the farm track, and 'the corn had this beautiful purple shadow and different blues; cerulean, ultramarine and phthalo blues'. His work is about this beauty in the multiplicity of nature, whether it be colour, light, or biodiversity.

He was drawn to nature from an early age, drawing birds and butterflies. As a teenager he kept an aviary, to which the RSPB brought injured birds. This interest in the natural world infuses his paintings: 'I subconsciously identify every bird that I see, and most trees and flowers', he says, and describes how this affects the way he paints the natural landscape. When painting trees he subtly alters their colour and shape depending on the species. Oaks, horse chestnut, beech and ash, he explains, have different variations of warmer 
greens, larch and pines have more blues. This depth of interest in the natural world is also reflected in his painting style:

This seems quite obvious but if you're painting distant trees very quickly and expressively where a tree is just laid down by a single vibrant brush mark, then the same thing applies. The knowledge of what that tree is informs that mark and the colour of it. So if I am sitting in a barren Yorkshire landscape with wind-scaped hawthorns and the odd oak, or a pulsing orange grove in Greece literally throbbing with life, it is the knowledge of all the individual parts that give a richness to the whole.

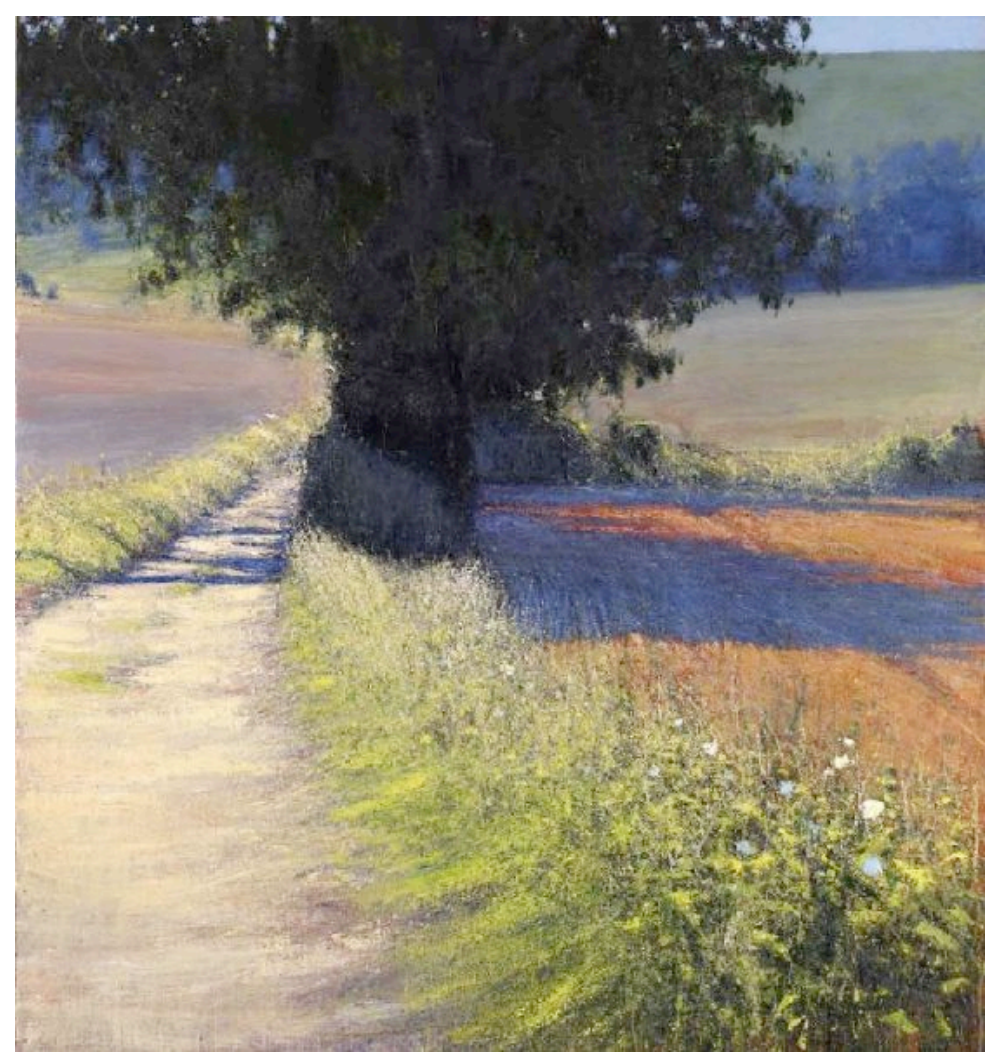

Andrew Gifford Farm Track at Little Heaven, late summer afternoon 2012 Oil on canvas $58 \times 53$ ins $(147.32 \times 134.62 \mathrm{~cm})$

Gifford bemoans the decreasing variety of species caused by overuse of pesticides, and celebrates the beauty that comes from undiminished biodiversity in parts of the world he has visited: 'The hedges haven't got half the species of birds they used to [...] When I look back at the paintings I'd paint of North Yorkshire, I'd paint big rape fields, strips of yellow, there's not so much of the hedgerows there'. In contrast to this was the biodiversity he describes in an orange grove, untreated with pesticides, which he painted in Greece. 'There were woodchat shrikes and cuckoos flying past and all these amazing birds and the buzz of the cicadas, you really felt that the place was throbbing, like a kind of a coral reef.' What Gifford loves in this painting is its 'vitality', as opposed to the North Yorkshire series, which he describes as desolate. 'I painted some paintings of this tree in a field, and it's like an old man in a desert $[\ldots]$ there's definitely a reflection of the amount of wildlife around me, if things are kind of throbbing and humming with life then that comes across in the painting.' 


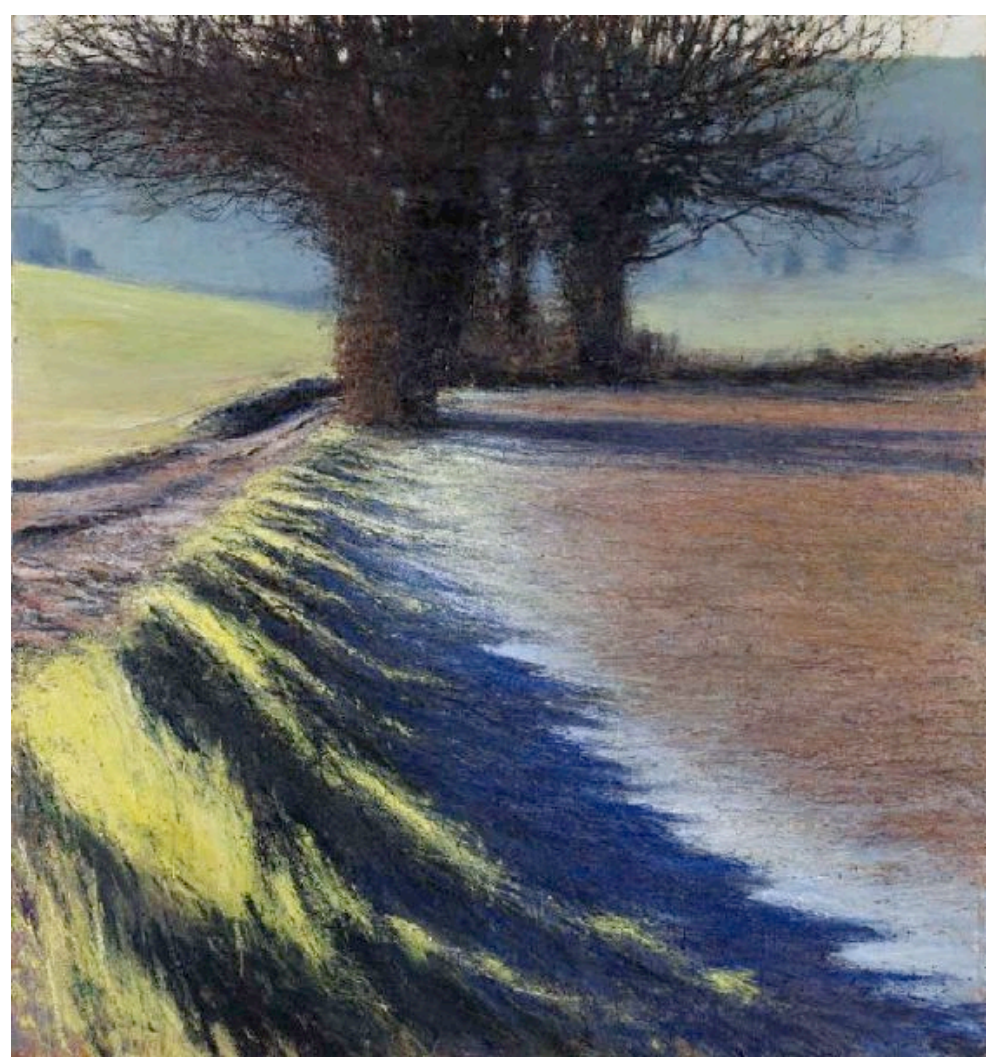

Andrew Gifford Farm Track at Little Heaven, Winter Frost 2012 Oil on canvas $58 \times 53$ ins $(147.32 \times 134.62 \mathrm{~cm})$

As well as traditional painting, the exhibition includes Gifford's 'line drawings'. These are based on the figurative landscapes in the set, a process he has practised for over a decade. He explains the works:

My distillation paintings are taking all the colour elements from a painting. It's horizontal because it's landscape but say there are strips of colour, I'll have roughly the same areas of colour, the same surface area if you think like that. So hopefully when you look at it you get the same feeling from the painting as you do when you look at the figurative version of it. It's just a different format and maybe a bit calmer and more meditative.

Gifford tends to choose what he describes as 'un-iconic' views: his aim is to allow people to see the beauty of ordinary things and then to find that beauty in the world around them: 'The views where people would go, "What the hell are you painting that for" and then they'd come back a few hours later and go "Oh my God, it's brilliant, I'd never have seen that as a painting" and therefore that makes them look at the world differently. It makes you look at simple things, the beauty in (them)'.

But the 'beauty' in Gifford's work is far from an idealisation: it retains a very modern sense of the complexity of the natural world in relation to humanity:

I'm really not interested in painting places that man hasn't had an impact on, so in some ways when I'm painting nature, I am painting man's 
impact on it [...] I wouldn't want to travel to the Scottish highlands and paint because it's beautiful already. l'd rather just write on a gallery wall, 'Go to the Scottish Highlands, they're beautiful'. What you can do with painting is you can paint quite ordinary things and manipulate them through the paint. My paintings aren't romantic.

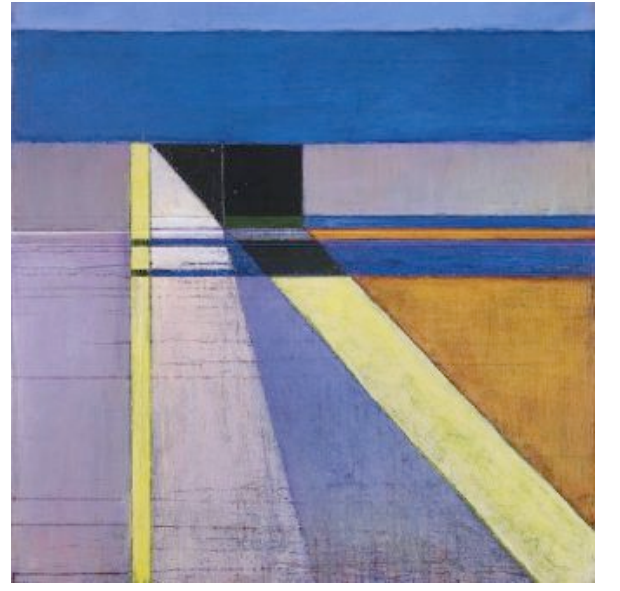

Andrew Gifford

Little Heaven Summer Morning Line Painting 2013 Oil on canvas $391 / 4 \times 391 / 4$ ins $(100 \times 100 \mathrm{~cm})$

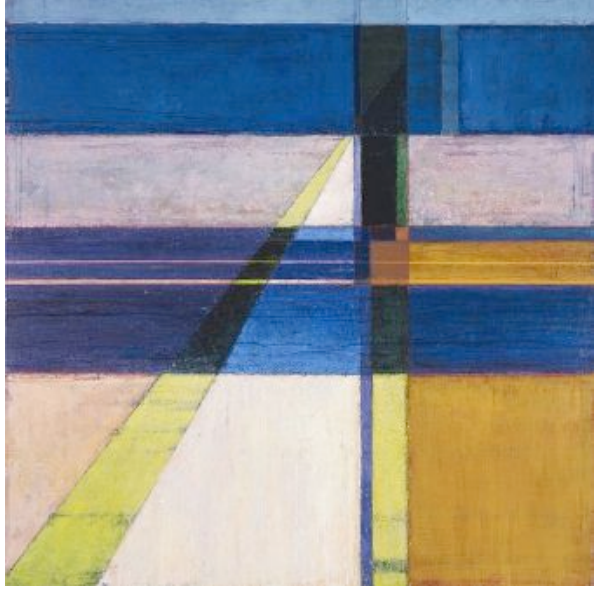

Andrew Gifford

Little Heaven Summer Afternoon Line Painting 2013 Oil on canvas $391 / 4 \times 391 / 4$ ins $(100 \times 100 \mathrm{~cm})$

The beauty in Gifford's art comes not from traditionally sublime views of 'pure' nature, which he eschews, but instead from an expanded redefinition of nature and beauty to include all of our interaction with the environment, including the processes of artistic apprehension and production. 'When I'm painting the landscape outside it's very much a reaction to what I'm seeing, whereas when you paint in the studio there's something much more poetic about it. You're looking much more at the painting for the painting's sake. You're not just reacting to the landscape, you're actually then looking at the painting and thinking "that tone's not right, I'll change that tone". In the first few years of landscape painting, as a student, Gifford insisted on completing his paintings in front of the landscape, without studio revisions. He eventually abandoned this practice as part of the expansion from the direct reaction to the environment, to instead incorporate the artist's reflective interpretation of that response. 'Those paintings, when I look back at them, they were a lot simpler, you gain things and lose things, because when I was young there was probably more energy in them, more vigour, a bit more expressionist, but very much simpler, there wasn't as much glazing.' Now, however, sketches done in front of the landscape are brought into the studio and worked on extensively, creating a richness of surface, and transforming the works with glaze.

There's a kind of poetic process which goes on afterwards, sometimes l'll just darken a whole area for the sake of the painting, it won't be for the sake of likeness to the landscape, but you're trying to convey the feeling of the landscape and what it means to you, so there's more of a richness and concentration when you're working away from it because it's not just a reaction to it. 
Gifford's landscapes then, like his urban paintings, are, as he says, rooted in the present, and in painterliness. They are a re-examination of our relationship with, and our feelings and respect for, the environment. Nature, rather than being something 'other', is expanded to include the viewer. As Gifford says, 'I wouldn't want to be labelled as an environmental artist. I'm just an artist, but I love painting the living world. It's just something that I'm very concerned about and I hope those things will be reflected.'

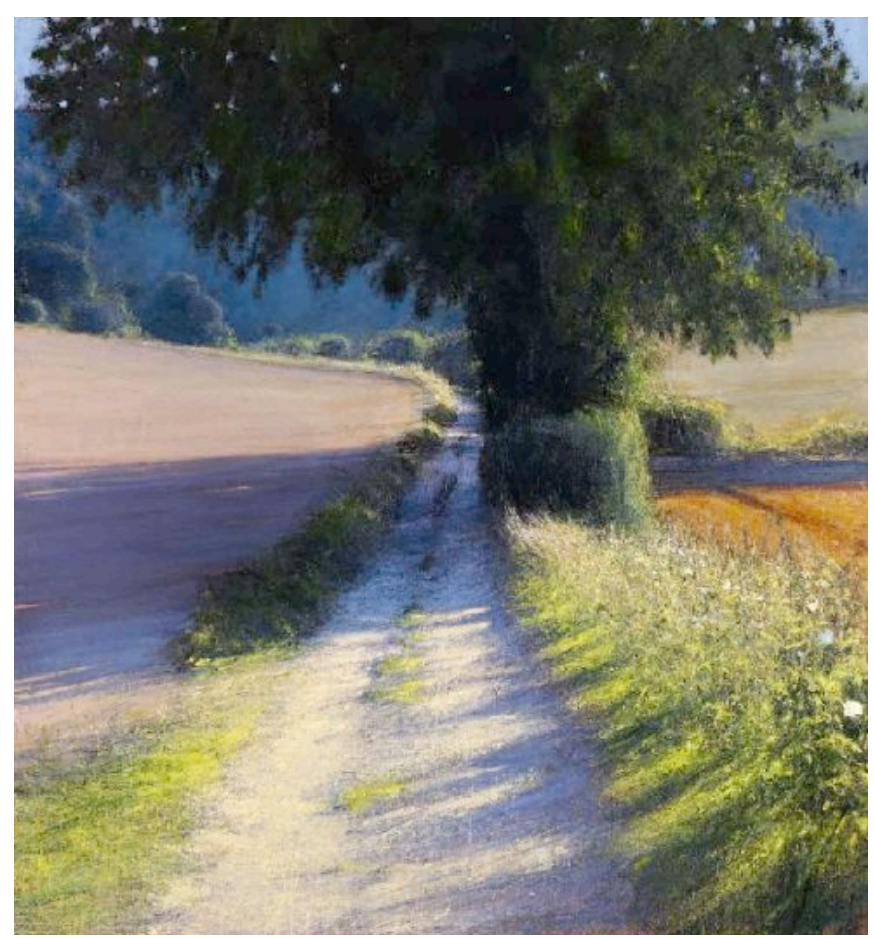

Andrew Gifford Farm Track at Little Heaven, late summer morning 2012 Oil on canvas $58 \times 53$ ins $(147.32 \times 134.62 \mathrm{~cm})$

\section{Birkbeck, University of London}

The 'Little Heaven' exhibition ran from the $24^{\text {th }}$ August to $20^{\text {th }}$ September at the Mildmay Gallery at Glyndebourne (Lewes, East Sussex BN8 5UU). For more information on the exhibition and on Andrew Gifford's works, see the John Martin Gallery website: http://www.jmlondon.com/artists/andrew-gifford/

Images by kind permission of the John Martin Gallery, London. Not to be used or redistributed without permission from the John Martin Gallery. 